Received: 2012.07.17 Accepted: 2013.01.07 Published: 2013.06.05

Authors' Contribution: Study Design A Data Collection B Statistical Analysis C Data Interpretation D Manuscript Preparation E Literature Search F Funds Collection G

\author{
A 1 Suresh Jaywantrao Bhosale \\ BF 1 Ashok Yadavrao Kshirsagar \\ C 1 Sushil Jalindar Deshmukh \\ D 1 Sunil V. Jagtap \\ E 1 Yodesh B. Langade
}

\title{
Squamous cell carcinoma of the breast
}

1 Department of Surgery, Krishna Institute of Medical Sciences, Maharashtra, India 2 Department of Pathology, Krishna Institute of Medical Sciences, Maharashtra, India

\begin{abstract}
Patient: Female, 60
Final Diagnosis:

Primary squamosus cell carcinoma of the breast

Symptoms:

-

Medication:

Clinical Procedure:

Mastectomy

Specialty:

Oncology

Objective:

\section{Rare disease}

Background:

Primary squamous cell carcinoma (SCC) is a very rare malignancy of the breast. It is a tumour of the elderly age group. Pure squamous cell carcinoma of the breast can deviate from epidermis, the nipple or the epithelium of deep-seated epidermoid cyst or squamous metaplasia on chronic inflammation background.

Case Report: $\quad$ Our case is a 60-year-old female patient who presented with a lump in her left breast. Left-side modified radical mastectomy was done. It was histopathologically diagnosed as squamous cell carcinoma of the breast (SCCB). There was no axillary node involvement. After one and half years, the patient presented with breathlessness and weakness. Investigations revealed lung metastasis with pleural effusion, and postoperative chemotherapy was given. The patient has attended regular follow-ups for the last 8 months.

Conclusions: The prognosis of this disease is highly uncertain and the treatment options are unclear and controversial. There is inadequate literature and treatment guidelines are lacking.
\end{abstract}

Key words: $\quad$ squamous cell carcinoma of the breast (SCCB) • chemotherapy • modified radical mastectomy

Full-text PDF: http://www.amjcaserep.com/download/index/idArt/883934

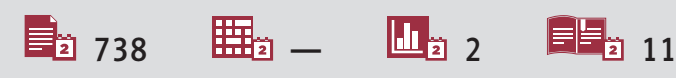




\section{Background}

Squamous cell carcinoma of the breast is a rare malignant neoplasm. Criteria for diagnosis include: 1) greater than $90 \%$ of the malignant cells of squamous cell origin, 2) tumor independent of the overlying skin and nipple, and 3) other sites of primary squamous cell carcinoma to be ruled out.

These tumors are thought to represent less than $0.1 \%(0.04 \%$ to $0.075 \%$ ) of all breast malignancies. Clinical and radiographic characteristics are not specific, the tumors are refractory to treatment, and prognosis is poor. We report this case because of its rarity.

\section{Case Report}

A 60-year-old woman came with complaints of a lump in her left breast since 10 months.

On examination there was a $3 \times 3 \mathrm{~cm}$, painless, mobile and hard lump in her left breast with involvement of the nipple and no axillary lymphadenopathy. Mammography revealed a tumor in the left breast, with microcalcifications. FNA was positive for malignant cells. A biopsy was performed, with results suggestive of infiltrating duct carcinoma. All routine hematological and biochemical examinations were normal. Chest x-ray was normal. Left-side modified radical mastectomy was done. On gross examination, the lesion showed cystic changes and yellow serous changes. The histopathological diagnosis was consistent with squamous cell carcinoma of the breast, with all surgical margins free of malignant cells (Figures 1 and 2). There was no axillary nodes involvement. Metastatic disease was ruled out. The patient had no history of skin cancer, nor did she have any skin, oral or anal lesions. Estrogen receptor (ER) and progesterone receptor (PR) status was negative.

Although post-operative chemotherapy was advised, the patient did not follow up. The patient came back to us after one and half years with breathlessness and generalized weakness. Further investigations revealed metastases to lungs, with pleural effusion. The patient was started on chemotherapy with paclitaxel and carboplatin combination. The patient received 6 cycles of chemotherapy, and has been keeping regular follow-up appointments since.

\section{Discussion}

Primary squamous cell carcinoma of the breast is very rare. It is called primary pure squamous cell carcinoma when the malignant cells are all of the squamous cell type, there is no relation with the skin, and if there is no indication for a primary

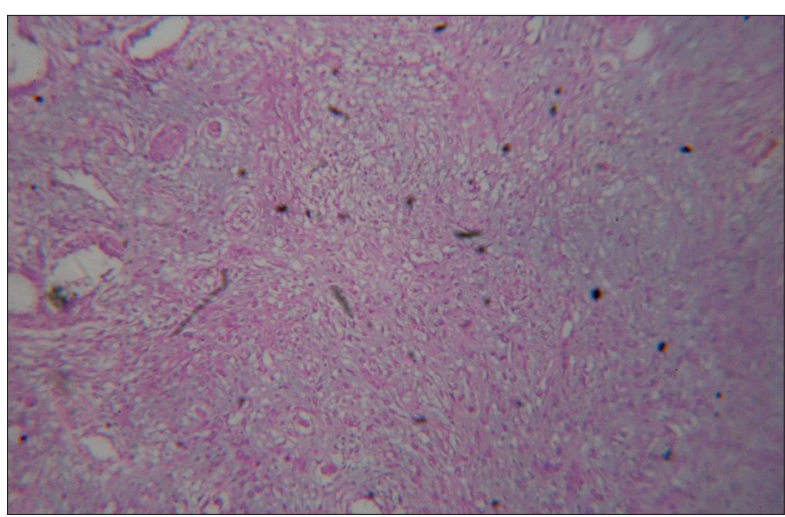

Figure 1. Showing squamous cell carcinoma.

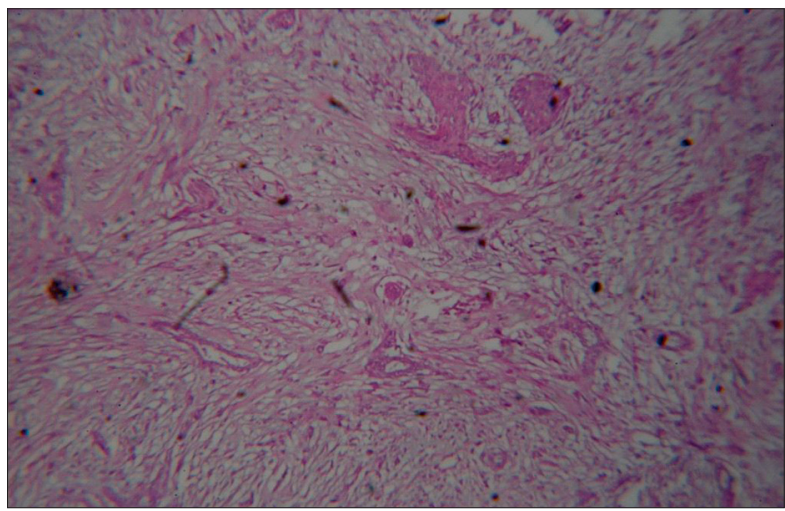

Figure 2. Also showing squamous cell carcinoma.

location somewhere else in the body $[1,2]$. It is important to distinguish this type from mixed tumours, where some patches of squamous cells can be found in adenocarcinoma of the breast and from metastasis of squamous cell carcinoma that originated elsewhere. The etiology and pathogenesis of squamous cell carcinoma of the breast is still unclear. It has been suggested that it may be a very extreme form of squamous cell metaplasia, developing into an adenocarcinoma. This could also explain the mixed forms [3]. Moreover, squamous cell metaplasia is also seen in cysts, chronic inflammations, abscesses and adenofibromas [4]. If these disorders can evolve into carcinomas, this may explain the occurrence of primary squamous cell carcinoma. This hypothesis is further supported by many cases in which primary squamous cell carcinoma is reported after its initial appearance as a benign disorder (abscess or after implantation of a breast prosthesis or after radiation therapy) [2,4-8]. In our case, however, there was no such pre-existent abnormality. In the literature this type of breast carcinoma occurs only in elderly women. In addition to a presentation with inflammation, the average size of the tumour is larger than adenocarcinoma of the breast $[1,4,9]$. There are no typical findings on the mammogram. Ultrasound may show a complicated cyst or an inflammatory process. A biopsy should be obtained. In our case, fine-needle aspiration showed malignant cells. The conclusion of the report, 
infiltrating duct carcinoma, was incorrect. In retrospect, the conclusion was not justified.

Squamous cell carcinomas are reported to result in less lymphatic spread than adenocarcinomas. In $10-30 \%$ of cases there is lymph node infiltration at the time of surgery $[4,9]$. In contrast, about $30 \%$ of patients will develop distant metastasis. Squamous cell carcinomas are generally hormone receptor-negative $[1,2,4,5,9]$. It is recommended to give patients similar adjuvant therapy but the radiosensitivity of squamous cell carcinomas is uncertain. The 5-year survival is $67 \%[4]$.

\section{References:}

1. Siegelmann-Danieli N, Murphy TJ, Meschter SC et al: Primary pure squamous cell carcinoma of the breast. Clin Breast Cancer, 2005, 3: 270-72

2. Zoltan TB, Konick L, Coleman RJ: Pure squamous cell carcinoma of the breast in a patient with previous adenocarcinoma of the breast: a case report and review of the literature. Am Surg, 2001; 67(7): 671-73

3. Stevenson JT, Graham DJ, Khiyami A, Mansour EG: Squamous cell carcinoma of the breast: a clinical approach. Ann Surg Oncol, 1996; 4: 367-74

4. Behranwala KA, Nasiri N, Abdullah N et al: Squamous cell carcinoma of the breast: clinico-pathologic implications and outcome. Eur J Surg Oncol, 2003; 29: 386-89

5. Wrightson WR, Edwards MJ, McMasters KM: Primary squamous cell carcinoma of the breast presenting as a breast abscess. Am Surg, 1999; 65(12): 1153-55
It is still debatable whether investigations such as PET scans, in search of distant metastases or a primary squamous tumour site, should be performed $[10,11]$.

\section{Conclusions}

Primary squamous cell carcinoma of the breast is rare. Its existence and possible evolution of an apparently benign disorder underlines the importance of pathological examination of complicated cysts and breast abscesses. The role of adjuvant therapy is unclear.

6. Tan YM, Yeo A, Chia KH, Wong CY: Breast abscess as the initial presentation of squamous cell carcinoma of the breast. Eur J Surg Oncol, 2002; 1 : 91-93

7. Talmor M, Rothaus KO, Shannahan E et al: Squamous cell carcinoma of the breast after augmentation with liquid silicone injection. Ann Plast Surg, 1995; 34(6): 619-23

8. Singh H, Williams SP, Kinsella V, Lynch GR: Postradiation squamous cell cancer of the breast. Cancer Invest, 2000; 4: 343-46

9. Gupta G, Malani AK, Weigand RT, Rangenini G: Pure primary squamous cell carcinoma of the breast: A rare presentation and clinicopathologic comparison with usual ductal carcinoma of the breast. Pathol Res Pract, 2006; 6: 465-69

10. Gupta RK, Dowle CS: Cytodiagnosis of pure primary squamous-cell carcinoma of the breast by fine-needle aspiration cytologie. Diagn Cytopathol, 1997; 3: 197-99

11. Healy CF, Feeley L, Leen E, Walsh TN: Primary squamous cell carcinoma of the breast: value of positron emission tomography scanning in confirming the diagnosis. Clin Breast Cancer, 2006; 5: 413-15 